\title{
Pemberdayaan Masyarakat Miskin Berbasis Kearifan Lokal
}

Saharuddin

\begin{abstract}
ABSTRAK
Kearifan lokal yang berkembang di masyarakat, pada dasarnya merupakan strategi adaptasi yang memang muncul dari dalam masyarakat itu sendiri dalam membenahi masalahmasalah sosial yang berkenaan dengan kehidupan masyarakat itu sendiri. Kearifan lokal merupakan hasil interaksi antara masyarakat dengan lingkungannya, sehingga dengan kearifan lokal, sangat diperlukan untuk membantu masyarakat itu secara mandiri. Kearifan lokal menjadi inti dari usaha mengentaskan kemiskinan yang ada dan tumbuh di masyarakat sebagai sasaran dari proses penerapan program pengentasan kemiskinan. Pengembangan kesejahteraan sosial atau juga pembangunan komuniti (community development) termasuk didalamnya program pengentasan kemiskinan dapat dilaksanakan dengan penerapan yang sesuai melalui kacamata komuniti setempat sebagai obyek sasaran.
\end{abstract}

Katakunci: pemberdayaan, kearifan lokal, masyarakat miskin

\section{PENDAHULUAN}

Paradigma pembangunan nasional telah bergeser dari pengutamaan pendekatan top down ke arah lebih memperkuat proses-proses pembangunan dari bawah yang lebih mengedepankan peran aktif masyarakat, yaitu menempatkan masyarakat sebagai titik sentral pembangunan (people central development). Program pembangunan yang dilaksanakan merupakan jawaban dari kebutuhan masyarakat setempat. Sedangkan program pemberdayaan masyarakat, merupakan usaha untuk memperkuat kapasitas masyarakat agar mampu mewujudkan dan meningkatkan harkat dan martabat masyarakat setempat, termasuk didalamnya menanggulangi kemiskinan.

Pemerintah, dunia usaha dan LSM telah banyak menghabiskan energi, mengeluarkan kebijakan, strategi dan program penanggulangan kemiskinan, namun tingkat kemiskinan terutama di masyarakat asli masih belum banyak berkurang. Selama ini kebijakan penanggulangan kemiskinan dilakukan dengan pendekatan leader-follower hierarchy model, yang lebih mengedepankan kebijakan makroekonomi dan memisahkan antara kebijakan makroekonomi, mikroekonomi dan kebijakan sosial. Kebijakan makroekonomi ditempatkan sebagai penentu utama, sedangkan kebijakan sosial ditempatkan paling ujung untuk menangani dampak sosial ikutan (Alhumami, 2008).

Sudah saatnya pendekatan tersebut diganti dengan pendekatan terpadu antara makroekonomi, mikro-ekonomi dan sosial guna dapat membangun sinergi antar sektor. 
Kebijakan seperti ini lebih berorientasi pada kesinambungan dalam jangka panjang, dan sangat efektif sebagai strategi untuk memberantas kemiskinan. Dalam pendekatan seperti ini, penanggulangan kemiskinan dimulai dengan mengurai akar masalah dan sumber penyebabnya sehingga intervensi kebijakan pun ditujukan secara langsung untuk mencegah semakin meluasnya kemiskinan. Sektor sosial yang paling pokok menjadi sasaran kebijakan mencakup: pemerataan akses pendidikan, pelayanan kesehatan dan gizi, penyediaan air bersih dan sanitasi, penyediaan pangan, pengendalian pertumbuhan penduduk, dan lain-lain. Untuk itu biaya investasi sektor sosial perlu ditingkatkan secara ikremental dengan tetap mempertimbangkan proporsi pengeluaran untuk sektor infrastruktur ekonomi (Alhumami, 2008).

Dalam kasus Indonesia, dimana dengan keluarnya UU Otonomi Daerah Nomor 32 tahun 2004, peluang ke arah pembiayaan sektor sosial secara lebih kongkrit menjadi sangat terbuka. Hal ini dapat diwujudkan karena pemerintahan daerah memiliki kebebasan yang luas untuk menterjemahkan kebijakan nasional di bidang penanggulangan kemiskinan dan menyesuaikannya dengan kondisi setempat, termasuk menggunakan kearifan lokal sebagai input dalam penanggulangan kemiskinan di tingkat daerah. Dengan demikian maka kebijakan nasional lebih mendapat apresiasi di tingkat daerah, dan kearifan lokal mendapatkan tempat sebagai salah satu input dalam kebijakan penanggulangan kemiskinan di tingkat daerah.

Masalahnya adalah bahwa pada masa sekarang ini keberadaan kearifan lokal kurang diperhatikan dalam usaha penanggulangan kemiskinan, bahkan mulai terancam oleh nilai-nilai luar. Kebanyakan unsur-unsur dari nilai luar tersebut tidak dapat sepenuhnya diadopsi oleh masyarakat asli karena berbagai keterbatasan yang ada pada mereka. Padahal kehidupan sosial ekonomi masyarakat asli tidak dapat dipisahkan dari mekanisme dan kearifan lokal. Karena itu pemberdayaan masyarakat berbasis kearifan lokal sangat diperlukan untuk menopang kebijakan penanggulangan kemiskinan.

Berkaitan dengan kearifan lokal, terdapat lima isu strategis yang perlu diperhatikan dalam pemberdayaan masyarakat asli, sebagai input penanggulangan kemiskinan pada tingkat masyarakat, yaitu: (i) Menghormati dan menjunjung tinggi Hak Asasi Manusia, (ii) Komitmen global terhadap pembangunan sosial masyarakat adat sesuai dengan konvensi yang diselenggarakan oleh ILO, (iii) Isu pelestarian lingkungan dan menghindari keterdesakan komunitas asli dari eksploitasi sumberdaya alam yang berlebihan. (iv) Meniadakan marginalisasi masyarakat asli dalam pembangunan nasional, (v) Memperkuat nilai-nilai kearifan masyarakat setempat dengan cara mengintegrasikannya dalam disain kebijakan dan program penanggulangan kemiskinan.

Model pemberdayaan masyarakat berbasis kearifan lokal mengandung arti peletakkan nilai-nilai setempat sebagai input penanggulangan kemiskinan. Dalam hal ini kebijakan penanggulangan kemiskinan perlu menempatkan kearifan lokal sebagai input pokok dalam kebijakan penanggulangan kemiskinan. Istilah peletakan nilai-nilai setempat (kearifan lokal) disini lebih dimaknai sebagai apresiasi terhadap praktek-praktek penanggulangan kemiskinan yang diinisiasi oleh pelaku-pelaku 
tingkat lokal dengan menjadikan kebijakan nasional sebagai rambu-rambu dalam membangun kerjasama sinergitas pada berbagai sektor dalam penanggulangan kemiskinan tersebut.

Berdasarkan latar belakang di atas, maka focus tulisan ini adalah isu kebijakan penanggulangan kemiskinan dengan belajar pada praktek-praktek implementasi kebijakan penanggulangan kemiskinan di daerah. Sampai mana kebijakan tersebut telah mempertimbangkan kearifan lokal dan sampai mana pula kearifan itu bisa menjadi salah satu media dan atau sebagai input dalam upaya membangun sinergi antara pendekatan makroeknomi, pendekatan mikroekonomi dan pendekatan pada sektor-sektor sosial (seperti disebutkan di atas).

\section{KONSEP-KONSEP POKOK}

\section{Perubahan Budaya dan Aktivitas Ekonomi}

Masyarakat Indonesia dalam kenyataannya tinggal dan menetap di wilayah-wilayah yang berbeda-beda antara satu dengan yang lainnya, seperti masyarakat pantai, masyarakat pegunungan, masyarakat pedesaan, masyarakat perkotaan, masyarakat dengan komunikasi lancar dan masyarakat di pedalaman dengan sarana komunikasi yang terbatas. Masing-masing individu sebagai warga masyarakat tersebut menunjukkan tingkah laku yang spesifik dan identitas tertentu pula dalam golongangolongan sosial yang berlaku. Masing-masing golongan sosial terikat pada suatu rasa kebersamaan sebagai satu kesatuan sukubangsa. Satu suku bangsa bisa terdiri dari berbagai kebudayaan, dan ini berkaitan erat dengan lingkungan manusia dalam sukubangsa tersebut tinggal. Akhirnya satu sukubangsa bisa terdiri dari beberapa masyarakat yang masing-masing anggota masyarakatnya menunjukkan tindakan dan tingkah laku yang berbeda antara satu dengan lainnya walaupun semuanya tergolong dalam satu sukubangsa. Bila dilihat lagi, tingkah laku-tingkah laku yang terwujud atau yang diwujudkan tersebut, mempunyai keteraturan-keteraturan yang berpola yang mempunyai arti dalam pengkategorisasian interaksi-interaksi yang terjadi. Hal inilah yang menghasilkan berbagai bentuk komuniti dan masyarakat yang ada di Indonesia yang dapat diklasifikasikan secara umum dalam berbagai pola kehidupan yang berbeda-beda satu sama lain sesuai dengan aturan adat istiadatnya masingmasing yang berfungsi sebagai model referensi..

Rangkaian model-model referensi tersebut didasari pada nilai-nilai budaya yang merupakan inti dari suatu kebudayaan. Nilai budaya terdiri dari pandangan hidup (world view) dan keyakinan (belief), keduanya dibungkus oleh ethos (pedoman etika berkenaan dengan baik dan tidak baik). Kebudayaan adalah sistem pengetahuan yang digunakan oleh manusia untuk membentuk tindakan mereka, dan menginterpretasikan perilaku orang lain (Spradley,1987:3). Pengetahuan budaya atau nilai-nilai budaya tersebut kemudian diwujudkannya dalam pengunaan simbol dan atribut-atribut budaya yang akan memberikan ciri budaya tertentu. Didalam interaksi sosial seseorang juga akan menggunakan pengetahuan budaya tersebut untuk melakukan penilaian sosial terhadap orang lain. Ia akan melakukan penggolongan-penggolongan sosial terhadap orang lain berdasarkan atribut-atribut budaya yang dikenakannya dimana ia mendasarkannya pada pengetahuan budaya yang dimilikinya. 
Ditilik dari kebudayaan yang ada di Indonesia, berbagai kebudayaan hidup dan berkembang di sini, kebudayaan-kebudayaan ini diwujudkan kedalam bentuk komuniti (community) dan masyarakat (society). Komuniti disini yang dimaksudkan adalah sekelompok manusia yang mendiami wilayah tertentu dimana seluruh anggotanya berinteraksi satu sama lain, mempunyai pembagian peran dan status yang jelas, mempunyai kemampuan untuk memberikan pengaturan terhadap anggota-anggotanya (Warren, Cottrell dalam Ndraha: 1990); sedangkan masyarakat merupakan sekumpulan orang yang mendiami wilayah tertentu dan anggotanya bisa berinteraksi antar masing-masingnya dan bisa juga tidak saling mengenal, masingmasing anggotanya menduduki status dan peranan tertentu yang sudah disediakan.

Dari pengertian ini tampak bahwa komuniti adalah merupakan bentuk kecil dari suatu masyarakat, dimana dalam komuniti seluruh anggotanya saling mengenal dan saling berinteraksi satu sama lain dan bahkan dalam beberapa kondisi, komuniti ini mempunyai latar belakang kekerabatan yang sama, artinya seluruh anggotanya sekerabat, seperti dalam komuniti-komuniti kesukubangsaan yang jumlah anggotanya kecil. Sedangkan masyarakat, mempunyai anggota tidak semuanya saling berinteraksi satu sama lain dan bahkan ada yang tidak mengenal satu sama lain tetapi bertindak dan bertingkah laku dalam aturan yang disepakati bersama dan yang tampak adalah peranan-peranan dari masing-masing anggota sebagai suatu sistem.

Dipakainya istilah komuniti lokal terkait pada adanya aturan dan nilai serta struktur sosial individu-individu yang terdapat di dalamnya, artinya bahwa dalam komuniti lokal semua anggota saling mengenal dan berinteraksi antara satu individu dengan individu lainnya, bisa mempunyai sejarah asal mula yang sama kemudian struktur sosial yang ada biasanya didasari pada jenjang sosial usia dan jenis kelamin. Komuniti lokal ini bisa terdiri dari berbagai jatidiri (identitas) kesukubangsaan, akan tetapi mempunyai aturan dalam bertindak yang sama atau kebudayaan yang sama yang dipakai untuk berhubungan satu dengan lainnya. Sedangkan tidak menggunakan istilah komunitas karena komunitas mengacu pada bentuk equilibrium tanpa struktur sosial, hubungan yang ada adalah hubungan pribadi .

\section{Perubahan Budaya dan Aktivitas Ekonomi}

Perubahan kebudayaan pada dasarnya akan terjadi ketika lingkungan mengalami perubahan dan juga komposisi penduduk yang berubah serta munculnya ide-ide baru dari para pendukung kebudayaan yang bersangkutan. Sehingga secara umum, perubahan kebudayaan dapat ditengarai sebagai perubahan dari luar yang terdiri dari perubahan lingkungan (alam, sosial dan binaan); dan perubahan dari dalam masyarakat itu sendiri yaitu adanya inovasi dan juga perubahan struktur penduduk.

Perubahan dari luar seperti perubahan lingkungan alam, mau tidak mau akan menggeser pengetahuan untuk dapat beradaptasi dengan lingkungan yang telah berubah tersebut demi pemenuhan kebutuhan manusia. Sehingga pergeseran pengetahuan ini akan menciptakan sebuah tingkah laku baru yang berbeda dari sebelumnya dengan lingkungan yang berbeda. Mislanya ketika orang tersebut pindah ke kota, maka lingkungan alamnya akan berganti sehingga pengetahuan bercocok tanam dengan teknik pertanian sudah tidak dapat digunakan lagi dan penggantinya adalah berusaha untuk mengadaptasikan diri dengan menggunakan 
pengetahuannya guna dapat mewujudkan tingkah lakunya agar dapat hidup di lingkungan baru.

Perubahan lingkungan sosial menciptakan strategi baru guna mewujudkan tingkah lakunya yang semula tidak dapat dipakai lagi karena sudah tidak sesuai dengan polapola sosial yang ada sebelumnya, seperi perubahan dari kebersamaan dalam masyarakat di pedesaan, akan berganti pada bentuk individual di masyarakat perkotaan. Karena dalam kehidupan masyarakat kota, pola kebersamaan sudah tidak dapat dipertahankan lagi. Tetapi sebagai awal dari proses adaptasi perubahan ini, kadang-kadang pola kebersamaan masih tetap dipakai guna proses adaptasi, tetapi lambat laun akan berubah menjadi individual.

Perubahan dari dalam biasanya berupa perubahan ide dan gagasan dari seorang individu warga masyarakat yang kemudian ide dan gagasan tersebut didifusikan ke warga lain dan menjadikannya pedoman bagi tingkah laku yang ada. Perubahan ide dan gagasan biasanya berupa penemuan-penemuan baru demi efisiensi dalam kehidupan masyarakat, sehingga pola hidup dari masyarakat akan mengalami pergeseran dan kemudian mengalami perubahan.

Ketika kebudayaan mengalami perubahan, yaitu perubahan dalam konteks ide dan gagasan maka akan terjadi perubahan pada bentuk-bentuk tingkah laku dari anggota masyarakat. Perubahan ide dan gagasan yang ada dalam pengetahuan kebudayaan suatu komuniti atau masyarakat akibat dari adanya akulturasi pada dasarnya dimulai dari interaksi sosial yang terjadi antara dua atau lebih kelompok sosial dengan budayanya masing-masing. Perubahan ide dan gagasan sebagai bentuk perubahan kebudayaan tentunya dilandasi pada bentuk pranata yang ada dan tersedia yang bisa mengadaptasikan bentuk baru yang berasal dari luar masyarakat sebagai bentuk lingkungan yang harus dipahami oleh masyarakat yang bersangkutan.

Dalam konteks perubahan kebudayaan yang ada dalam kehidupan masyarakat atau komuniti, maka tugas pokok dalam penerapan program ini bukan hanya dipikul oleh pemerintah saja, akan tetapi pihak-pihak swasta dan perusahaan juga ikut berpartisipasi. Bagi pihak swasta, khususnya perusahaan, kegiatan penerapan program dengan melihat pada kemampuan masyarakat atau komuniti yang didasari pada social capital yang ada atau sering dikatakan sebagai kearifan lokal yang berkembang di daerah setempat ini adalah merupakan penerapan tanggung jawab sosial perusahaan (corporate social responsibility) yang diembannya.

\section{Kearifan Lokal}

Bangsa Indonesia dianugrahi dengan berbagai ragam dan bidang kearifan lokal, dalam berbagai bentuk, diseluruh nusantara. Perajin Batik atau tradisi memproduksi batik baik di Jawa dan telah berkembang di luar pulau Jawa, kerajinan ukir patung suku Asmat di Papua juga merupakan bagian dari kearifan lokal (local wisdom) atau kearifan tradisional dalam masyarakat kita dapat dan atau telah menjadi tumpuan aktivitas ekonomi komunitas tertentu.

Dalam bidang lingkungan, bagaimana masyarakat Lampung mempunyai cara melestarikan hutan damar yang getahnya merupakan sumber penghasilan. Masyarakat Bali dengan subaknya yang terkenal, sampai sekarang memelihara tradisi tersebut untuk terus menjamin hasil pertanian padi dari sawahnya. Dalam 
bidang-bidang lainnya satu deretan panjang mengenai kearifan lokal/traditional dapat dikembangkan menjadi kekuatan yang berarti dalam mendorong keberdayaan masyarakat khususnya secara ekonomi

Dalam bidang jasa, kita temui dikota-kota besar tukang sol (perbaikan) sepatu yang berkeliling menyusuri gang-gang sempit menawarkan jasanya untuk memperbaiki berbagai jenis alas kaki. Sebagian besar dari mereka berasal atau pendatang dari daerah Garut Selatan. Kita juga dapati pengusaha barang bekas khususnya besi/baja (scrap) yang kebanyakan berasal dari Madura. Dipasar tradisional dan pusat-pusat pertokoan kecil, kita sering menemui seseorang dengan buku catatan kecil yang mendatangi pedagang satu persatu. Mereka ini adalah tukang kredit yang kebanyakan datang dari Tasikmalaya. Jadi Tasikmalaya terkenal bukan hanya dengan kerajinan bambu dan pandan, tapi juga dengan tukang kredit.

Apa yang telah diutarakan diatas dan masih banyak lagi, adalah bagian dari budaya kita yang berbentuk kearifan lokal. Kearifan lokal tersebut telah lahir dan berkembang dari generasi ke generasi seolah-olah bertahan dan berkembang dengan sendirinya. Kelihatannya tidak ada ilmu atau teknologi yang mendasarinya, tetapi sesungguhnya, telah terjadi proses transfer of knowledge yang berlangsung secara alami. Tanpa ada pendidikan atau pelatihan formalpun penerusan keahlian itu terus berkembang, meskipun dalam beberapa dekade terakhir telah diperkuat dengan berbagai pelatihan formal yang diselenggarakan pemerintah. Kearifan tersebut telah terpelihara dan tumbuh dalam masyarakat itu sendiri. Awalnya jangkauan pasar mereka adalah pasar lokal dan kebutuhan masyarakat setempat dan kadang-kadang meluas kedesa-desa tetangganya. Tapi sekarang ini kita dapat melihat jangkauan mereka sudah menjadi nasional malah terkadang internasional. Ini menampakkan bahwa kearifan lokal menjadi suatu wujud tulang punggung aktivitas ekonomi dalam komunitas tertentu.

Meluasnya pasar dan tuntutan akan peningkatan volume produk menjadikan jenis kearifan lokal tertentu perlu didorong dan diberdayakan agar lebih maju. Dan bahkan dapat mend penggunaan teknologi dan inovasi baru. Di beberapa wilayah seperti Ceper dan Cibatu misalnya, pemerintah mendirikan pusat-pusat pelayanan teknis dan menyediakan permesinan modern yang bisa dimanfaatkan masyarakat perajin logam. Masuknya tenaga-tenaga terdidik juga telah membawa dampak peningkatan produktifitas, dengan menerapkan berbagai metode produksi dan manajemen. Kearifan melanggengkan kemampuan yang dimiliki masyarakat sebagai suatu kearifan lokal mereka inilah yang perlu ditelaah dan dikembangkan melalui pendekatan pemberdayaan. Kearifan lokal itu, merupakan bagian dari budaya bangsa yang perlu dimanfaatkan, dipertahankan dan dikembangkan.

\section{Pemberdayaan Masyarakat: Konsep dan Kebijakan}

Salah satu tujuan pembangunan masyarakat adalah mendorong terjadinya perubahan dan pembiasaan warga dari penerima pembangunan dan pelayanan (pasif) menuju warga yang kapabel dan berpartisipasi (aktif) menentukan pilihan, menangani isu bersama dalam masyarakat. Pendekatan seperti itu difahami sebagai paradigma pembangunan berpusat manusia (people centered development) yang menempatkan masyarakat sebagai fokus maupun sumber utama pembangunan. Pendekatan itu dipandang sebagai suatu strategi alternatif yang menjamin komplementaritas dengan 
pembangunan bidang lain. Orientasinya adalah pada penumbuhan kualitas, mendorong kemampuan, dan kapasitas warga masyarakat terlibat dalam keputusan penting menyangkut kehidupannya.

Pembangunan masyarakat dapat difahami melalui tiga orientasi yaitu: (1) upaya pengadaan pelayanan dasar sebagai kelengkapan dari strategi kebutuhan pokok, diidentikkan dengan peningkatan pelayanan sosial dan pemberian fasilitas sosial, seperti fasilitas kesehatan, peningkatan gizi, pendidikan, dan sanitasi untuk kesejahteraan masyarakat; (2) upaya terencana untuk mencapai tujuan lebih kompleks dan bervariasi, guna mencapai tujuan sosial yang lebih sulit diukur, seperti keadilan, pemerataan, peningkatan budaya, kedamaian, serta adanya kesempatan yang sama; dan (3) upaya meningkatkan kemampuan manusia untuk berbuat dan meningkatkan potensialitasnya, memobilisasi antusiasmenya untuk berpartisipasi aktif dalam proses pengambilan keputusan atau kebijakan terkait dengan diri mereka ${ }^{1}$.

Korten dan Uphoff (1981), mengkritik pendekatan top down atau cetak biru pembangunan sosial yang sering mengabaikan partisipasi rakyat. Pendekatan kawasan bersasaran multisektor lebih menyukai partisipasi minimal. Yang terbaik adalah pendekatan pengelolaan sumber yang bertumpu pada masyarakat, mencakup partisipasi timbal balik dan otonom yang melahirkan reorientasi birokrasi secara mendasar ke arah keterkaitan lebih efektif dengan komunitas klien, termasuk reorientasi klien.

Kebijakan pembangunan masyarakat sering dikritik karena dianggap sebagai cara pemerintah menguasai rakyat secara politis, atau sebagai kompromi politik dan atau konspirasi tanpa menyentuh akar permasalahan, karena banyak program pembangunan tidak relevan dengan kondisi ril masyarakat. Dalam situasi tertentu, sering muncul klaim lokal bahwa kebijakan pembangunan adalah cara memaksakan kebijakan/ program pemerintah kepada lokal, meskipun seringkali program itu sesuai dengan kondisi lokal. Cara itu merupakan suatu mekanisme mengimplementasikan kebijakan pemerintah ke daerah. Keputusan pendanaan pusat yang melibatkan stakeholders lokal juga masih dianggap perpanjangan administrasi pemerintah pusat.

Upaya mendorong partisipasi stakeholder dalam pembangunan sosial dapat dilakukan melalui : (1) reorientasi birokrasi ke arah hubungan yang efektif dengan masyarakat melalui koalisi jaringan komunitas; (2) peningkatan rasa tanggung jawab dimana rakyat membangun diri sendiri, kesadaran memahami kebutuhan, masalah, kemampuan dan potensi mereka; dan (3) memperlancar komunikasi antara berbagai stakeholders lokal. Perlu penerapan prinsip penuntun yakni mendatangi rakyat, hidup bersama rakyat, belajar dari rakyat, merencanakan dan kerjasama dengan rakyat, mulai dengan diketahui rakyat, bangun dan kembangkan, ajari dengan contoh (learning by doing), memperkenalkan pola bukan memamerkan, menunjukkan

\footnotetext{
${ }^{1}$ Moeljarto, T, 1987. Politik Pembangunan; Sebuah Analisis, Konsep Arah dan Strategi, Tiara Wacana, Yogyakarta, hlm. 21-22.
} 
sistem bukan menciptakan rintangan, menyelaraskan persepsi, mengubah pola-pola secara kreatif, dan memberikan kebebasan berkreasi ${ }^{2}$.

Arah kebijakan program pemberdayaan masyarakat seringkali difokuskan pada upaya peningkatan kesadaran hak asasi manusia, hak hidup, rasa memiliki, partisipasi politik dalam pembuatan keputusan, integrasi dan pembangunan sosial, hak kultural, menghargai paham dan pendapat orang lain, rasa tanggung jawab sosial sebagai ukuran keberhasilan, selain diarahkan pada peningkatan pelayanan sarana dan prasarana dasar, kegiatan sosial kerakyatan serta pengembangan ekonomi kerakyatan berbasis potensi lokal dan pemanfaatan peluang pasar yang lebih luas. Pembangunan sosial akan mudah dicapai, bila masyarakat diberdayakan untuk ikut memberikan pelayanan kepada masyarakat lainnya, terlibat dalam proyek, serta banyak mengetahui permasalahan dan kebutuhan lingkungannaya, termasuk mampu mengambangkan diri menunju kemandirian ekonomi dibawah proteksi kebijakan pemerintah. Untuk mewujudkannya, diperlukan keterlibatan sektor swasta sesuai kadar tanggung jawabnya, serta LSM yang memiliki tanggung jawab ekslusif atas pembangunan sosial. Mereka biasanya mendorong taktik konfrontasional dengan menekan badan pemerintah agar responsif problematika masyarakat ${ }^{3}$. Serta mendesak pihak swasta (koorporasi) mengembangkan program CSR (cooporate sosial responsibility).

Konsep pembangunan berpusat rakyat dengan fokus pada pemberdayaan masyarakat merupakan sebuah strategi pendekatan, dimana insisiatif kreatif dari rakyat menjadi dasar kebijakan pembangunan. Membangun kesejahteraan masyarakat perlu melibatkan rakyat dalam prosesnya agar penentu kebijakan memahami seksama persoalan sesungguhnya. Faktor kunci keberhasilannya adalah: (1) komitmen penentu kebijakan; (2) kemampuan fasilitaor mendampingi masyarakat; (3) lingkungan mendukung perubahan bersama; dan (4) ada jaminan untuk dapat berubah dan hasil studi sebagai sumber atau referensi dalam membuat kebijakan. Diperlukan intervensi dalam penguatan dan pemahaman masyarakat untuk mengetahui dan mengembangkan sektor tertentu melalui pendekatan partisipasi. Hal itu dapat membantu masyarakat mengetahui dan memahami proses pengelolaan sumber daya, sehingga pelaksanaan program pembangunan menjadi lebih berkesinambungan.

\section{KERANGKA ANALISIS}

Tulisan ini menggunakan dua model analisis, yakni: (1) analisis hubungan ekologis sebagai dasar pembentuk aktivis masyarakat dengan basis kearifannya dan aktivitas hubungan multipihak yang kemungkinan mempengaruhi dan terpengaruholeh aspekis aspek kearifan lokal; (2) analisis hubungan antar pihak di atas wilayah ekologis dimana masyarakat kearifan lokal terjadi.

Analisis hubungan ekologis mengasumsikan bahwa kearifan lokal terbentuk di atas basis ekologis. Kondisi ekologis yang berbeda menghasilkan bentuk kearifan yang berbeda pula. Bentuk-bentuk ekologis menghasilkan pola hubungan khas antara manusia dan komponen lingkunganngya. Pola khas hubungan ekologis atas dasar

\footnotetext{
${ }^{2}$ Moeljarto, loc.cit., h. 51.

${ }^{3}$ Ibid, h. $90-91$. 
kearifan lokal tersebut selanjutnya menentukan pola hubungan dengan pihak luar (multi stakeholder) (Gambar 1). Berbagai pengaruh pengetahuan dan teknologi luar serta penetrasi pasar dianggap berpengaruh pada pola-pola hubungan dalam pemanfaatan sumberdaya alam. Karena itu bentuk-bentuk kearifan lokal mengalami perubahan secara gradual, termasuk juga perubahan-perubahan kearifan lokal.

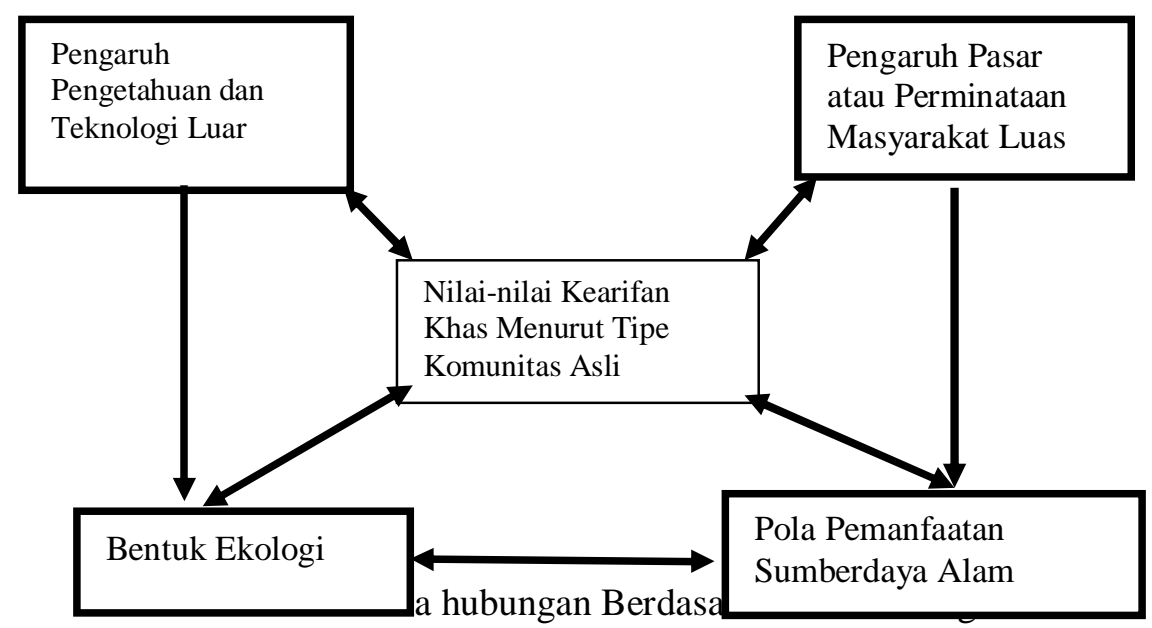

Dalam konteks pemberdayaan pemberdayaan masyarakat atau community empowerment pada dasarnya diarahkan pada pembentukkan mata pencaharian baru yang merupakan mata pencaharian tambahan bagi masyarakat atau setidak-tidaknya merupakan perluasan akses aktivitas ekonomi baik kuantitas maupun kualitas dalam bentuk peningkatan nilai tambah, penambahan skala produksi atau penambahan mata pencaharian baru . Dalam konteks hubungan multipihak, usaha perluasan mata pencaharian tersebut terkait dengan berbagai kebijakan pelibatan masyarakat dalam berbagai program pembangunan, khususnya pemberdayaan ekonomi, program pemberdayaan semestinya melibatkan hubungan antara perusahaan pemerintah, dalam hal ini pemerintah daerah masyarakat setempat. Pemerintah dalam hal ini berperan sebagai regulator dan juga sosialisator, pihak swasta berperan sebagai pelaku penerapan pengembangan masyarakat dan komuniti sendiri berperan dalam pertisipasinya memanfaatkan kesempatan ekonomi. Khususnya bagi lembaga swasta, sesuai dengan Undang-undang Perseroan Terbatas, keterlibatan dalam pemberdayaan masyarakat merupakan suatu kewajiban moral untuk komuniti (community development) dengan pendekatan pemberdayaan masyarakat atau community empowerment.Hubungan antara ketiga pihak tersebut ditampilkan pada gambar 2. berikut. 


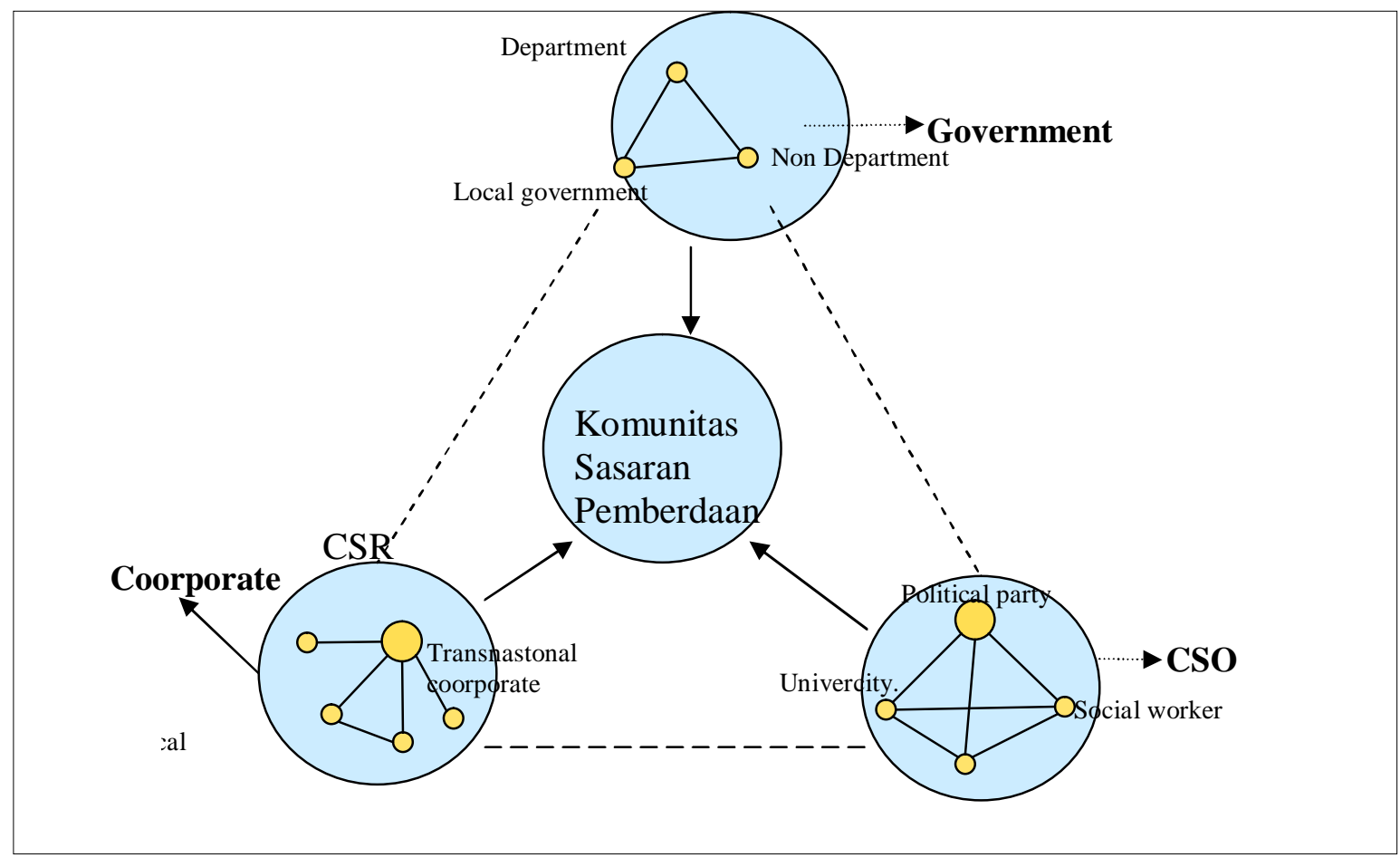

Gambar 2.: Model Pemberdayaan Masyarakat oleh Lintas Pelaku

Dalam studi ini model hubungan multipihak di atas, dipakai untuk menganalisis sampai mana program-program pembangunan yang dilakukan oleh pemerintah, swasta dan LSM mendasarkan aksinya pada kearifan masyarakat setempat, baik dalam hal penetapan program, jenis kegiatan, mekanisme pelaksanaan kegiatan, pednganggaran dan pemanfaatan hasilnya. Dalam konteks hubungan tiga pihak tersebut di atas, bisa dianalisis ke arah mana kedekatan suatu komunitas atau dari mana suatu komunitas memperoleh akses yang lebih besar disertai dengan pendayagunaan kearifan masyarakat setempat. Tujuannya adalah untuk menemukan pranata sosial dan aktivitas produktif masyarakat yang dapat dijadikan daya dukung bagi penerapan program baru ini. Dari sini pola pengembangan pemberdayaan berbasis kearfian lokal dapat dikembangkan secara intensif atas dukungan pemerintah dan masyarakat sipil.

Dalam penerapan program pemberdayaan, hal pokok yang menjadi orientasi adalah segi ekonomi kerakyatan, sarana dan prasarana dasar dan lingkungan serta pranata sosial. Secara ekonomi program ini dapat meningkatkan pendapatan penduduk, tidak merusak lingkungan yang ada serta tidak merubah secara drastis sistem sosial masyarakat sehingga gegar budaya dapat diminimalisasikan. Keterlibatan anggota komuniti, menjadikan sasaran pengembangan wilayah dan pemberdayaan masyarakat berbasis kearifan lokal dapat didukung oleh komuniti setempat, yang secara langsung, berkaitan dengan wilayah tersebut. Dengan demikian jurang atau ketimpangan social dan gap structural antara antara pemerintah swasta dan komuniti lokal secara perlahan dapat diperkecil. Hal itu menjadi target akhir dari program 
pemberdayaan masyarakat berbasis kearifan lokal dan menjadikan lingkungan sebagai subyek yang perlu dilestarikan dalam pengembangan wilayah dan pembangunan masyarakat lokal.

\section{HASIL PENGAMATAN}

\section{Karakteristik Sosial Budaya}

Kajian dilaksanakan secara terfokus di Desa Pasar Seluma Kecamatan Seluma Selatan dan Desa Rawasari Kecamatan Seluma Timur, Kabupaten Seluma, Provinsi Bengkulu dimaksudkan untuk mendalami fenomena kehidupan suatu komunitas yang melewati proses perubahan yang mendasar. Beberapa alasan yang dapat dikemukakan dalam menetapkan komunitas tunggal sebagai pusat perhatian adalah (1) desa tersebut mengalami pergeseran dari pertanian pangan dan nelayan menjadi perkebunan kelapa sawit rakyat, (2) Pasar Seluma adalah desa berpenduduk suku Serawai asli

Usahatani kelapa sawit mulai berkembang di desa ini sejak awal tahun 1990-an setelah sebuah perusahaan masuk mengembangkan kelapa sawit di kawasan tersebut. Masuknya perkebunan kelapa sawit perusahaan segera diikuti oleh perkebunan kelapa sawit rakyat dalam dengan pola KKPA, sehingga hampir seluruh warga memiliki kebun kelapa sawit. Kelapa sawit telah menjadi primadona ekonomi utama. D i antara $185 \mathrm{KK}$ yang ada di desa Pasar Seluma saat ini hanya 9 KK yang tidak memiliki kebun kelapa sawit. Kesembilan KK tersebut hingga kini masih memfokuskan perhatiannya pada kegiatan nelayan, meskipun usaha mereka terbatas di pinggiran. Sementara KK yang lain telah berpindah dari kegiatan nelayan menjadi petani kebun kelapa sawit, meskipun aktivitas nelayan masih sesekali dilaksanakan.

Selanjutnya aspek yang akan lebih disoroti dalam tulisan ini adalah sebagai berikut. (1) Bagaimanakah kearifan lokal lokal berhubungan kuat dengan upaya-upaya penanggulangan kemiskinan pada sektor perikanan dan pertanian. Bagaimanakah kearifan lokal suatu daerah berkonstribusi dan mengalami dinamikanya sendiri ketika bersentuhan dengan sektor-sektor modern?.

Di masyarakat Bengkulu ini terjadi perubahan mata pencaharian yang banyak disebabkan oleh datangnya orang-orang dari luar daerah Bengkulu untuk hidup dan mengembangkan usaha di Bengkulu. Keberadaan orang-orang luar Bengkulu ini menyebabkan ketertarikan dari orang-orang local untuk 'mencoba' mata pencaharian baru, sehingga terjadi perpindahan pola mata pencaharian yang selama ini digelutinya.

Tetapi dalam perjalanan waktu, kegiatan mata pencaharian baru ini terdapat beberapa kendala yang ternyata menyebabkan peralihan kembali menuju ke pola mata pencaharian lama yang selama ini ditinggalkan. Proses perubahan ini mewarnai kehidupan social budaya yang ada. Ketika dalam proses perubahan ini terdapat banyak penduduk sebagai anggota masyarakat yang termasuk dalam kondisi miskin dari sudut pandang pemerintah karena tidak mempunyai pekerjaan tetap dan hanya didominasi oleh kelompok social lain. 
Desa Pasar Seluma pada dasarnya adalah sebuah desa nelayan tradisional. Ekologi perairan tergolong unik, dimana komunitas hidup di sekitar muara dengan ombak yang cukup keras di sekitar pantai. Di luar garis daerah pasang surut tersebut merupakan wilayah penangkapan ikan oleh nelayan luar desa. Masyarakat setempat tidak mampu secara optimal mengakses sumberdaya laut sekitar mereka, karena: (i) keterbatan penguasaan sumber-sumber modal, dan (ii) keterbatasan pengetahuan dan keterampilan sehingga tidak dapat mengakses kawasan yang memiliki potensi penankapan tersebut. Nelayan hanya melakukan penangkapan dengan menggunakan jaring/pukat tarik hingg 200 meter ke arah tengah.

Walaupun desa Pasar Seluma dekat dengan laut, tetapi laut bukan merupakan keahlian warga desa Pasar Seluma. Pada masa lalu mereka melaut hanya dipinggir saja, dengan cara membuat tenda di pantai dan dengan menggunakan peahu kecil untuk memasang jarring dan pancing. Hingga tahun 1990-an hanya tig keluarga di desa pasar Seluma yang tidak melaut. Mereka meninggalkan anak-anak mereka untuk tinggal di laut menangkap ikan. Mereka melaut dua periode dalam seminggu, yakni hanya diantarai oleh hari pasaran. Mereka berangkat pada hari Senin dan kembali pada hari Rabu untuk menjual hasil ke Desa Pasar Tais; kemudian berangkat lagi pada hari klamis dan Kembali pada hari Sabtu. Jadi rumah asli mereka hanya digunakan pada malam Kamis, dan hari Sabtu dan hari Minggu.

Meskipuan pada masa sekarang ini banyak plihan usaha bagi masyarakat, tetapi perkembangan penduduk yang cepat di kawasan ini akan tetap menjadi satu persoalan bagi upaya peningkatan kesejahteranan masyarakat di masa depan. Pada masa sekarang satu keluarga sudah cukup memenuhi kebutuhan dasarnya dari kelapa sawit. Tetapi kebutuhan tenaga kerja di sektor kelapa sawit sudah jenuh, dan tidak ada lagi kesempatan kerja di sektor pertanian lainnya. Artinya jika tidak ada upaya lain, maka pengangguran akan semakin besar dan sulit untuk diatasi. Jika hanya mengandalkan perkebunan kelapa sawit, maka dalam beberapa tahun ke depan diperkirakan tidak lagi memadai, meskipun saat ini menjadi primadona ekonomi penduduk. Karena itu, jalan satu-satunya yang sementara ini dipikirkan oleh warga adalah "kembali ke laut" dengan berusaha meningkatkan kapasitas warga untuk menjadi nelayan. Tantangannya pun semakin berat, karena bukan sekedar untuk menjadi nelayan seperti pada masa lampau, tetapi betul-betul memilih jalur nelayan sebagai profesi generasi muda.

Nelayan di desa Pasar Seluma sejak dahulu hingga saat ini adalah nelayan pinggiran yang mengoperasikan pukat mandre, suatu jenis pukat yang dioperasikan di pinggiran dengan panjang maksimal 150 meter. Pengoperasian pukat tersebut memerlukan tenaga dua hingga tiga orang. Hingga kini kelompok nelayan seperyi ini masih sekitar 2 persen dari total nelayan pinggiran sebelum masuknya perkebunan kelapa sawit.

Saat ini usaha nelayan di didukung oleh 3 orang toke ("makru"), yakni pembeli ikan hasil tangkapan dan menjualnya. Mereka terutama menampung hasil nelayan dengan kadang-kadang memberikan pinjaman modal seperlunya di bawah kapasitas tangkapan. Ketiga toke tersebut menjual hasil tangkapannya di desa Pasar Tais, sekitar 40 km dari desa Pasar Seluma. 


\section{Pemberdayaan Yang 'Berjalan'}

Dalam rangka mendukung usaha nelayan di desa Pasar Seluma, pemerintah telah memberikan 2 unit sampan nelayan motor tempel dengan peralatan apa adanya dua tahun silam. Setelah itu disusul bantuan dari Dinas Sosial sebanyak 4 unit motor tempeltanpa alat tangkap. Bantuan ini oleh warga setempat dianggap belum menjamin kehidupan nelayan secara berkelanjutan. Tetapi seluruh bantuan tersebut kini tidak ada lagi bekasnya

Selain itu, upaya pemerintah membantu nelayan melalui program LEPM3 (Lembaga Ekonomi Pemberdayan Masyarakat Mitra Mina) dengan mengeluarkan dana sebesar Rp. 600 juta untuk 20 orang dalam bentuk bantuan pemberian kapal kecil dan alat tangkap secara berkelompok serta membangun tempat pelelangan ikan di daerah muara. Bantuan itu diberikan secara berkelompok 10 sampai 15 orang anggota.

Selain program LEP-M3 dari Dinas Perikanan, Dinas Sosial juga memberikan perahu tempel pada tahun 2007 sebanyak 7 buah. Selain bantuan alat tangkap, pemerintah daerah juga memberikan usulan berupa proyek Pelabuhan Pendaratan Ikan (PPI) di atas tanah seluas 8,6 Ha. Proyek tersebut merupakan usulan dari pemerintah desa untuk mengantisipasi perkembangan kehidupan yang semakin kompleks di masa depan. Proyek ini semata-mata didasarkan pada pertimbangan potensi alam tidak didasarkan pada konteks kehidupan sosial nelayan di kawasan tersebut. Asumsinya adalah meskipun saat ini di lokasi tersebut tidak terdapat aktivitas nelayan secara intensif, tetapi ke depan diharapkan dapat menjadi satu pilihan titik pertumbuhan dengan memanfaatkan potensi muara bagi pendaratan nelayan kecil. Hal ini karena pada musim tertentu banyak kapal dari berbagai daerah menangkap ikan di kawasan desa Pasar Seluma. Hasilnya di bawa ke Bengkulu, lalu oleh pedagang keliling di jual lagi ke desa Pasar Seluma dan desa sekitarnya. Karena itu pihak pemerintah desa beranggapan bahwa jika PPI dibangun, maka nelayan luar dapat masuk ke muara dan akan menjadi "guru besar" baru bagi nelayan Pasar Seluma. Dengan demikian warga setempat memiliki banyak ruang untuk memperoleh kesempatan kerja baik menjadi nelayan maupun peluang usaha lainnya di sekitar PPI.

Program-program pengembangan bagi masyarakat nelayan dengan atribut-atribut ekonomi baru memerlukan pendampingan yang lebih serius dalam aktivitasnya. Sebab nelayan tergolong tipe komunitas yang sulit melakukan transformasi secara cepat. Dengan pembangunan PPI diharapkan akan dapat menampung banyak tenaga kerja terserap di dalamnya, sehingga dapat menyerap sejumlah tenaga kerja yang terus bertambah. Pada saat ini setiap keluarga memiliki 5 anak karena itu prediksi kebutuhan tenaga kerja di masa depan sudah dapat dilakukan. Katakanlah saat ini setiap keluarga memiliki 4 ha perkebunan kelapa sawit dengan anak 4 orang yang mau sekolah. Sementara ini dengan memiliki kebun kelapa sawit seluas 4 ha dianggap cukup memadai. Tetapi bagaimana dengan keturunannya ke depan, dan bagaimana pula dengan keluarga nelayan yang hanya mengandalkan kegiatan musiman? Inilah yang perlu diantisipasi ke depan.

Komoditas perkebunan rakyat yang berkembang di Provinsi Bengkulu meliputi kopi, karet, kelapa sawit, kelapa, coklat, pinang, cengkeh, kemiri, lada, aren, nilam, kapuk, 
navili, dan jahe. Usaha perkebunan itu kebanyakan dilakukan rumah tangga perkebunan rakyat yakni mencapai 335 ribu rumah tangga. Perusahaan yang berinvestasi di subsektor perkebunan sekitar 10 perusahaan dengan fokus pengembangan karet, kelapa sawit, coklat, dan teh.

Pengembangan kelapa sawit oleh perusahaan sudah dimulai pada awal tahun 1989 yakni di Mukomuko, Bengkulu Utara, dan Bengkulu Selatan. Luas lahan perkebunan besar swasta kelapa sawit pada tahun 1996 telah mencapai 33.683,8 ha (BPS 1997). Perkebunan kelapa sawit rakyat baru dikembangkan pada tahun 1994. Pada tahun 1997 produksi kebun kelapa sawit rakyat di Provinsi Bengkulu mencapai 10.853 ton dan terus meningkat menjadi 64.759 ton pada tahun 2000 (BPS Provinsi Bengkulu 2001).

Dilihat dari segi luas lahan, kelapa sawit di Provinsi Bengkulu pada tahun 2005 merupakan komoditas terbesar kedua yang diusahakan penduduk (BPS Provinsi Bengkulu 2006). Mesekipun demikian usaha perkebunan kelapa sawit pada dasarnya bukan pertanian asli Provinsi Bengkulu. Perkebunan kelapa sawit berkembang sebagai hasil interaksi antara warga setempat dengan perusahaan perkebunan kelapa sawit sejak pada awal tahun 1990-an. Diawali dengan adanya beberapa karyawan yang bekerja di perusahaan kelapa sawit dan tinggal menetap di daerah itu. Secara perlahan mereka kemudian menanam kelapa sawit sendiri di luar areal perusahaan. Kehadiran perusahaan dan adanya usaha perorangan dari luar untuk mengembangkan kelapa sawit mendorong warga setempat untuk mempelajari dari mengadopsinya sebagai pilihan aktivitas ekonomi baru. Secara kebetulan manager perusahaan dan pelaku-pelaku usaha kelapa sawit di sekitar desa adalah orang Batak, yang sekaigus menjadi tempat belajar pertanian kelapa sawit bagi warga setempat, maka mereka menganggap orang batak sebagai "guru besar" kelapa sawit. Penempatan orang batak sebagai "guru besar" kelapa sawit dapat ditunjukkan dengan kisah masuknya kebun kelapa sawit di desa Pasar Seluma yang mencerminkan hasil interaksi antara orang perorang warga desa Pasar Seluma dengan orang-orang Batak. Orang Batak dianggap "lebih tua" dari pada kelapa sawit. Sebelum kedatangan orang Batak, warga desa Pasar Selemu masih berpgang pada pepatah "dapat beras secupa, ika sejere ..... madar .... (istrahat)"

Proses konversi sawah di Bengkulu menurut Widiono (2008) terjadi dalam tiga tahap. Pertama, periode 1990-1993 yakni pencarian alternatif solusi atas masalah keterbatasan faktor edafik (tanah bergambut dan pasang surut) bagi produksi sawah. Kedua, periode 1993-1998 adalah penumbuhan kesadaran dan upaya meniru yang merupakan hasil pengamatan serta pertukaran pengalaman dengan para buruh PT AA dan migran etnis Batak. Ketiga, periode 1998-sekarang, yaitu pemilihan alternatif dan penerapan solusi. Pilihan untuk menanam kelapa sawit secara meluas terjadi setelah petani merasa memiliki pengetahuan yang cukup, ketersediaan modal, dan jaminan pembelian oleh pabrik kelapa sawit. Hal itu ditunjukkan dengan kesediaan petani mengikuti program pengembangan perkebunan kelapa sawit melalui skema KKPA.

\section{Pencarian Alternatif Solusi (Periode 1990-1993)}

Areal persawahan Desa Pasar Seluma terletak di sekitar muara sungai Seluma yang terpengaruh oleh pasang naik dan pasang surut laut. Selain itu keadaan tanahnya 
berawa. Sebagian areal sawah ditutupi oleh lapisan gambut.

Ketika permasalahan ekonomi kian menambah beban hidup rumah tangga petani dan produksi sawah dan perikanan tidak dapat diharapkan lagi, petani memperhatikan perkebunan kelapa sawit di sekitar desa mereka untuk mengatasi masalah ekonomi mereka. Hasil dari pengamatan dan perbincangan mengenai kebun kelapa sawit itu menumbuhkan bibit alternatif pemecahan hingga mereka menyandarkan harapan pada cocoknya lahan berawa untuk kelapa sawit. Pencarian alternatif solusi tidak menyulitkan mereka karena di sekitar desa terdapat perkebunan kelapa sawit milik PT AA yang membentang luas di atas lahan bergambut. Pada tahun 1993 kebun kelapa sawit PT AA mulai menghasilkan. Mereka berkesimpulan bahwa kelapa sawit yang ditanam di atas lahan bergambut mampu menghasilkan buah yang sangat baik. Ada juga responden yang merasa yakin tentang kelapa sawit melalui perkataan-perkataan orang dari luar desa pada saat bepergian ke kota atau di daerah lain.

\section{Penumbuhan Kesadaran dan Upaya Meniru (Periode 1993-1998)}

Secara khusus tidak ada aktor lain yang memberikan pengetahuan dan motivasi kepada petani desa penelitian untuk menanam kelapa sawit. PT AA yang mulai menanam bibit kelapa sawit di tahun 1990 mengabaikan penduduk desa sekitar termasuk desa penelitian, bahkan dalam perekrutan tenaga kerja sekalipun. Karena itu sekitar tahun 1990-1993, masyarakat masih bergantung pada sawah dan aktivitas nelayan pinggir. Masyarakat Desa Pasar Seluma setiap harinya dapat melihat para pekerja PT AA mempersiapkan lahan, menanam, dan merawat tanaman kelapa sawit, akan tetapi belum berkeinginan untuk meniru pekerjaan yang mereka saksikan tersebut.

Pada sekitar tahun 1993, Desa Pasar Seluma kedatangan migran etnis Batak. Mereka membeli lahan-lahan yang sebagian masih berupa hutan sekunder milik penduduk untuk dijadikan kebun kelapa sawit. Secara admisnitratif mereka menjadi penduduk Desa Pasar Seluma dengan lokasi permukiman di antara kebun mereka. Kedatangan orang-orang Batak ke wilayah Seluma ini tidak terlepas dari gelombang migran Batak ke Bengkulu untuk menjadi tenaga kerja di perusahaan-perusahaan perkebunan karet, kelapa sawit, dan kakao yang pada umumnya milik orang Batak. Kehidupan sehari-hari mereka dalam upaya menyatukan diri dengan etnis Serawai memungkinkan terjadinya pertukaran informasi dan pengetahuan mengenai budidaya kelapa sawit. Rupa-rupanya orang Batak ini jauh lebih mengetahui tata cara berkebun kelapa sawit termasuk adanya keyakinan hasilnya nanti akan dibeli oleh pabrik-pabrik pengolah kelapa sawit.

Kebun migran Batak yang dibangun di atas lahan rata-rata 2 ha tumbuh dan berkembang dengan baik sehingga menjadi contoh nyata sekaligus menjawab pertanyaan orang-orang Seluma yang selama itu beranggapan negatif terhadap kelapa sawit. Nyatanya petani biasa juga bisa mengolah lahan yang sebagian gambut itu menjadi kebun meski tak sebaik PT AA. Di permulaan interaksi dan sosialisasi etnis Batak, pada tahun 1995 tergeraklah dua orang etnis Serawai untuk mencoba meniru menanam kelapa sawit di atas lahan seluas 5 ha dengan membeli bibit dari orang Batak. Peneliti mewawancarai kedua orang itu. Menurutnya motivasi mereka mencoba menanam kelapa sawit adalah untuk meningkatkan kembali kondisi 
ekonomi orang Seluma yang kian memburuk akibat tanah-tanah mereka habis dijual kepada pendatang disamping banyaknya lahan yang dibebaskan oleh PT AA. Dengan keawaman dalam cocok tanam kelapa sawit, walhasil usaha mereka gagal, banyak pohon kelapa sawit yang mati diserang hama penyakit. Sungguhpun demikian, pengalaman pertama ini memicu mereka untuk lebih serius memperhatikan bagaimana para buruh PT AA bekerja dan migran Batak mengelola kebun kelapa sawit.

\section{Pemilihan Alternatif dan Penerapan Solusi (Periode 1998-sekarang)}

Setelah merasa yakin bahwa tanaman kelapa sawit dapat tumbuh dengan baik pada lahan-lahan mereka serta pertimbangan eksternal untuk menanam kelapa sawit semakin kuat, maka tidak ada jalan lain kecuali mengkonversi sawah mereka untuk menjadi areal kebun kelapa sawit. Hasrat yang kuat dalam diri petani tersalurkan dalam manifestasi kesediaan petani di desa penelitian menjalin kerjasama dengan pihak pemerintah daerah dalam pengembangan perkebunan kelapa sawit. Pada mulanya para tokoh masyarakat mengadakan musyawarah tentang tawaran pihak Dinas Perkebunan pada awal tahun 1998. Tampaknya dalam diri petani sudah ada kesiapan mental untuk menghadapi pilihan yang semakin terbuka lebar ketika pemerintah berupaya memfasilitasinya. Walhasil, musyawarah para tokoh tidak mengalami kesulitan dalam menyatukan pendapat. Kesepakatan di Tawaran dari pemerintah kepada para petani adalah fasilitasi Pemerintah Provinsi, Pemerintah Kabupaten, dan Dinas Perkebunan dalam hal pembiayaan dan fasilitasi teknis perkebunan kelapa sawit. Model pengembangan kelapa sawit yang direncanakan adalah kemitraan petani dengan PTPN VII. Petani mendapatkan pembiayaan dari Bank Pembangunan Daerah Bengkulu Selatan (BPD BS sekarang menjadi Bank Bengkulu Selatan) melalui skema Kredit Koperasi Primer Untuk Anggota (KKPA). Pihak PTPN VII yang berkedudukan di Pring Kecamatan Talo membeli semua produk kebun kelapa sawit petani peserta KKPA.

KKPA didasarkan pada SK Bank Indonesia Tahun 1998 No. 31/145.A/Kep/Dir/1998 mengenai sumber-sumber pembiayaan bagi koperasi, Menurut SK tersebut kredit pembiayaan perkebunan harus ditujukan kepada anggota koperasi primer dengan plafon maksimum 50 juta. Petani terhimpun dalam Koperasi Unit Desa (KUD). Kasus KKPA di desa penelitian, petani mendapat kredit sebesar 5,5 juta dalam bentuk bibit, pupuk, dan pestisida. KKPA Rawasari dimulai pada tahun 1998 sedangkan Pasar Seluma baru tahun 1999.

Jadi pada era sebelum tahun 1998, keinginan sebagian masyarakat desa penelitian untuk menanam kelapa sawit belum mendapat respon tindakan dari pemerintah. Camat sebagai aparat di atas kepala desa pada waktu itu tidak mampu mengambil tindakan meskipun usulan dari desa sudah disampaikan.

Sejak disampaikannya sumber pembiayaan KKPA melalui Kepala Desa, warga desa melalui kesepakatan KUD mengajukan diri sebagai penerima kredit. Desa Rawasari (KUD Sumber Makmur) jumlah pesertanya sebanyak 102 orang (total lahan 102 ha @ 1 ha) sedangkan Desa Pasar Seluma (KUD Ksatria) sebanyak 151 orang (total lahan 125 ha). Turunnya kredit dari BPD Bengkulu Selatan itu terbagi menjadi dua tahap. Desa Pasar Seluma tahap I 47 orang dan tahap II 104 orang. 
Dengan adanya fasilitasi kredit ini, petani di desa penelitian serentak menanam kelapa sawit pada periode tahun 1998-1999. Sebelum datangnya bibit, petugas dari Dinas Perkebunan datang ke balai desa untuk menjelaskan teknik bertanam kelapa sawit dan meminta para petani untuk segera mempersiapkan lubang tanam pada lahan masing-masing. Saat petani mulai menanam dan merawat kelapa sawit yang mulai tumbuh, semestinya sudah ada jaminan pembelian hasil kebun kelapa sawit oleh PTPN. Akan tetapi sampai dengan kebun mulai menghasilkan belum tercapai MoU (Memorandum of Understanding) antara Dinas Perkebunan dengan PTPN. Menghadapi kenyataan ini, hasil produksi kebun petani dijual ke pabrik-pabrik lain melalui toke kelapa sawit.

Praktis melalui KKPA, petani secara bersama-sama mengkonversi sawah menjadi perkebunan kelapa sawit. Harapan yang terpendam dalam diri petani tersalurkan dalam tindakan melalui fasilitasi kebijakan pemerintah. Tujuan petani tidak lain hanya untuk memperbaiki kondisi perekonomian yang sudah sekian lama terpuruk. Melalui usaha kelapa sawit petani mendapatkan sumber penghasilan yang jelas setiap kali panennya dijual ke toke.

Konteks perkembangan desa tempat terjadinya konversi sawah dapat digambarkan sebagai berikut. Keputusan menanam kelapa sawit yang ditempuh dengan jalan mengkonversi sawah merupakan suatu keputusan revolusioner pada diri petani karena kelapa sawit adalah jenis tanaman baru bagi petani. Terjadinya konversi sawah di desa penelitian merupakan hasil interaksi aktor petani dengan buruh PT AA, migran etnis Batak, dan Dinas Perkebunan yang terjadi dalam konteks perekonomian desa yang sedang merosot. Masyarakat Desa Pasar Seluma mengalami kekurangan akses terhadap sumberdaya hutan, kebun campuran, dan sawah akibat penempatan transmigrasi dan pencadangan lahan untuk perkebunan kelapa sawit salah satu perusahaan (PT AA).

Konversi sawah mengakibatkan penghasilan tetap rumah tangga petani bersumber dari hasil penjualan kelapa sawitnya. Semakin luas kebun seseorang, semakin bergantung pendapatannya pada kebunnya. Namun demikian, peran pendapatan yang bersumber dari pertanian sawah masih cukup tinggi, terutama pada petani golongan bawah dan menengah.

Sebagian besar informan dan responden yang diwawancarai menuturkan tentang suka-dukanya menjadi petani dimana bertahun-tahun perekonomian rumah tangganya tidak beranjak dari sekadar cukup. Setelah mengalami kehilangan akses terhadap sumberdaya hutan, kebun campuran, dan sawah/rawa akibat pemukiman transmigran, penduduk Desa Pasar Seluma mesti merelakan melepaskan lahan-lahan garapan mereka untuk pembukaan perkebunan kelapa sawit PT AA. Sekali lagi ini adalah masalah-masalah yang menambah beban ekonomi masyarakat Desa Pasar Seluma karena akses terhadap kebun campuran dan sawah-sawah semakin berkurang.

Masyarakat memiliki argumentasi sendiri ketika menyaksikan lingkungan sekitar mereka dibangun perkebunan kelapa sawit oleh perusahaan. Ada harapan mereka kelak akan dapat bekerja di kebun-kebun perusahaan. Ini yang dialami oleh masyarakat Desa Pasar Seluma sekitar tahun 1989. Menurut dokumen Inventarisasi Lahan BPN Provinsi Bengkulu tentang identifikasi lahan-lahan negara yang 
dicadangkan untuk PT AA dalam garapan masyarakat, dinyatakan bahwa masyarakat menginginkan desanya juga dikembangkan kebun kelapa sawit. Namun menurut beberapa informan, pada waktu itu masih ada keragu-raguan untuk menanam kelapa sawit. Mereka memang betul-betul baru "mendengar" nama tanaman kelapa sawit, disamping belum adanya pihak yang secara intens memotivasi masyarakat desa menanam kelapa sawit.

Kehadiran perusahaan bagi masyarakat desa Seluma merupakan berkah tersendiri. Mereka beranggapan bahwa kalau tak ada perusahaan masuk ke suatu daerah, maka hal itu menunjukan bahwa daerah tersebut adalah daerah tertinggal. Banyak hal yang bisa mereka pelajari, bisa diadopsi dan bisa menghasilkan pendapatan dari interaksi. Menurut mereka semakin banyak perusahaan, pasar makin banyak dan pertukaran dalam banyak hal dapat terjadi.

Dalam usaha mengembangkan kebun kelapa sawit warga memperolehnya dari dua jalur, yaitu: dari jalur masyarakat umum dan dari jalur dinas. Tetapi jalur dinas dianggap tidak memadai karena tidak menyeleksi mana yang dura (buah jelek) dan mana yang tenera (buah bagus).

Orang Batak sekarang menjadi perintis kebun kelapa sawit warga desa Pasar Seluma. Mereka memperkerjakan warga setempat mulai dari persiapan lahan, teknik penanaman, pemeliharaan sampai pemetikan termasuk didalamnya pemilihan bibit yang baik. Berbeda dengan perusahaan, mereka tak mau membagi pengetahuan dengan warga setempat soal pembibitan. Perusahaan berharap agar petani tidak membeli bibit di luar tetapi membelinya dari mereka. Melalui proses ini warga setempat memiliki pengetahuan dan keterampilan tentang usahatani kelapa sawit. Tak mengherankan, meskipun berbeda agama dengan orang Batak, tetapi mereka sangat menghpormati keberadaan mereka di kawasan tersebut.

Untuk membantu mengatasi permasalahan kesulitan ekonomi di desa dan memanfaatkan potensi lahan yang luas, maka salah satu tokoh setempat mengorganisir rekan-rekan terdekatnya untuk membangun perkebunan kelapa sawit. Mereka pun berinisiatif mendatangi oknum-oknum yang pernah menjanjikan sesuatu pada masa kampanye untuk menjadi anggota DPRD di Bengkulu. Pimpinan kelompok kecil ini kemudian pergi ke Bengkulu mencari orang yang pernah berkampanye dan berhasil berhasil menjadi anggota DPRD untuk menagih janjinya. Anggota DPRD yang dimaksud memberikan saran untuk berorganisasi terlebih dahulu. Lalu diberinya uang sebagai ongkos transportasi untuk menemui Kepala Dinas Perkebunan. Sementara pa Buyung tidak mengerti mengapa harus ke Dinas Perkebunan di Bengkulu. Oleh pihak Dinas perkebunan Bengkulu dia diberikan maasukkan tentang pembangunan kebun kelapa sawit dengan syarat berkoperasi.

Meskipun warga tidak mengerti apa itu koperasi - mereka hanya fahami bekerja secara berkelompok - tetapi syarat-syarat pembentukan koperasi tetap dipenuhi.Meskipun demikian tidak semua warga mau mengikuti gagasan yang dibawa dari kota tersebut. Hanya 49 orang dari 68 KK desa Pasar Seluma pada masa itu yang masuk dalam gagasan berkoperasi dan mau bergotong royong untuk membuka hutan pada musim kemarau. Ke 49 orang tersebut kemudian bekerja selama sekitar 6 bulan dan menghasilkan lahan bukaan seluas 50 ha. Pembakaran 
hasil tebangan atas lahan seluas 50 ha ternyata pembakkaran meluas hingga 150 ha. Akhirnya terjadi perebutan lahan di atas lahan 100 ha lahan yang kebakaran, yang pada akhirnya dibagi berdasarkan tingkat keaktifan dalam membuka lahan hutan. Lahan tersebut ditanami secara tak terarah. Kemudian diorganisasikan untuk menanam padi gogo.

Untuk membeli bibit padi godo mereka mengumpulkan uang secara bersama sehingga terkumpul uang sebesar Rp. 128.000,-. Dengan modal Rp. 28.000,tersebut mereka kembali berkonsultasi dengan anggota DPRD. Mereka kemudian mendapat rujukan ke Dinas Pertanian Provinsi dan dari sana mereka berhasil mendapatkan 1,2 ton benih padi gogo secara gratis. Benih inilah yang dibagi kepada 49 orang petani sesuai dengan kebutuhannya masing-masing. Seluruh perkerjaan dilaksnakan secara gotong royong pada hari Minggu dan Kamis, karena hanya pada hari inilah waktu bersama di darat.

Setelah menanam padi, dilanjutkan dengan menanam jagung, dan kacang tanah. Karena pekerjaan pertanian sudah semakin membutuhkan waktu, maka mulailah ke 49 orang ini bergeser dari usaha nelayan ke pertanian. Jadi munculnya komunitas petani dirintis oleh 49 keluarga nelayan.

Sudah menjadi kebiasaan petani di kawasan ini, dimana lahan yang pertama kali dibuka selalu ditanami pada dan palawija. Setelah itu, dua atau tiga tahun kemudian diganti dengan tanaman perkebunan. Bagi kelompok petani desa Pasar Seluma, obsesi mereka adalah menana kelapa sawit. Untuk itu mereka harus menempuh jalur panjang dan berliku.

Upaya kelompok 49 (pak Buyung dkk) untuk merealisakan perkebunan kelapa sawit didorong oleh rasa dendam atas kegagalan menjadi kepala desa. Setelah gagal menjadi kepala desa, maka dia berpikir bahwa tanpa menjadi kepala desa pun, dia dapat mengabdi kepada masyarakat.

Dalam proses pemilihan kepala desa dia mengalami kegagalan. Dia hanya dipilih oleh 17 orang. Ketujuh belas orang inilah yang kemudian menjadi tempat berdiskusi soal perkebunan kelapa sawit meski orang lain mencemohnya pada masa itu. Termasuk diantaranya yang mencomoh adalah yang disebutnya "kelompok 9" termasuk kepala desa terpilih. Mereka inilah yang sering menghalangi segala upaya untuk merealisasikan kebun kelapa sawit. Tetapi pak Buyung merasa lega atas kritikan mereka karena justru muncul setelah ia berhasil mewujudkan impiannya.

Diantara kelompok 9 tersebut kemudian melakukan aksi di lapangan dengan kembali mempersoalkan asal usul lahan. Mereka mengklaim bahwa di lahan kelapa sawit ada areal lahan mereka yang terambil oleh anggota koperasi. Anehnya adalah bahwa selama membuka lahan mereka tak mau ikut gotong royong. Demikian juga selama dua tahun pasaca pembukaan lahan ditanami padi dan palawija mereka tidak menggugat.

Meskipun gugatan mereka tanpa alasan, tetapi pak Buyung dan kawan-kawan memberikan lahan yang mereka klaim. Warga yang telah mendapatkan hak atas lahan tersebut dipindahkan ke tempat lain. Tetapi rupanya bukan lahan yang mereka minta, melainkan sekedar meminta kompensasi sebesar $\quad$ Rp. 300.000,- 
Permasalahan yang pakling berat adalah kalim keturunan pasira sehinga yang berujung di pengadilan dengan 29 kali persidangan. Klaim lahan pasira dipelopori oleh "kelompok 9" yang menyatakan bahwa lahan kelapa sawit adalah milik pasirah Bunga Mas. Pasirah adalah kepala pada satu marga yang di bawahnya terdapat beberapa deputi. Pada sat klaim tersebut, terdapat dua deputi yang masih hidup dan menjadi saksi atas kepemilikan lahan tersebut. Kesaksian kedua deputi tersebut di pengadilan adalah bahwa memang benar bahwa rombongan pasira pernah membuka lahan di kawasan itu pada tahun 1958. Tetapi mereka tidak memperoleh Izin dari Bupati setempat. Kesaksian inilah yang dianggap mengugurkan kaim warga atas lahan hutan yang dibuka yang kini telah berubah menjadi kebun kelapa sawit.

Sebagaimana diketahui bahwa usaha perkebunan kelapa sawit rakyat di desa Pasar Seluma dibangun dengan pola KKPA. Dalam hal ini skema pinjaman sudah ditetapkan per ha dengan pola pengembalian dalam bentuk cicilan dan hasilnya akan diserap langsung oleh pabrik melalui koperasi sampai dengan masa kredit lunas. Urusan pencairan dana dan pembangunan kebun difasilitasi oleh koperasi, sedangkan urusan pelunasan adalah tanggungjawab individu melalui koperasi. Dalam perjanjian kerjasama antara BPD dengan koperasi dan dengan anggota disebutkan bahwa petani wajib membayar ke BPD sebesar 15 persen dari penjualan TBS dan TBS harus dijual ke pabrik melalui koperasi.

Untuk tahap awal seluruh skenario berjalan mulus. Bahkan pihak-pihak yang tadinya menentang keberadaan KKPA berbalik dan mendukung atau menjadi anggota KKPA. Tetapi tuntutan warga terhadap koperasi meningkat tidak sekedar menjadi "broker" bagi petani tetapi juga ikut mengupayakan kebutuhan petani secara lebih luas.

Atas desakan kebutuhan dan optimisme kemampuan membayar dari hasil perkebunan kelapa sawit mereka, maka animo warga untuk memanfaatkan kredit melalui koperasi meningkat tajam. Dalam batas tertentu, pada awalnya koperasi mampu melayani warga, dengan catatan tidak melebihi platform pinjaman masingmasing, yakni Rp. 5,5 juta pada tahap I dan 7,6 juta pada tahap II. Tetapi dalam perjalanannya permintaan kredit oleh anggotan semakin meningkat hingga melampaui platform kredit masing-masing. Koperasi tidak sempat mempersiapkan diri untuk mengantisipasi peningkatan kapasitas pinjaman oleh para anggota tersebut. Pertimbangan koperasi untuk tidak memberikan pinjakam kepada petani dalam jumlah besar adalah sebagai berikut:

(1) Modal masih sangat terbatas.

(2) Jika salah satu anggota dilayani, maka seluruh warga yang lain juga harus dilayani.

(3) Beban petani masih sangat besar dari kredit awalnya (KKPA)

Kesempatan ini kemudian dimanfaatkan oleh para toke kelapa sawit yang juga merupakan anggota koperasi. Ironisnya pada saat yang sama, pihak bank melayani pemberian pinjaman kepada toke dalam kapasitas besar yang memungkinkan sang toke menopang usahanya. Toke tersebut memberikan laporan secara sepihak kepada bank tanpa melalui koperasi tentang perkembangan koordinasi TBS oleh koperasi dan yang bersangkutan menjamin akan memberikan dukungan bagi 
pengembalian kredit oleh anggota. Pengajuan kredit oleh toke kemudian dipenuhi oleh Bank meskipun pihak koperasi pernah memberikan masukkan ke bank bahwa pinjaman tersebut akan berdampak pada koordinasi pemasaran TBS milik petani.

Tetapi gagasan pengurus koperasi tidak dipenuhi oleh pihak bank BPD Bengkulu, dan pihak bank memutuskan tetap memberikan kredit kepada toke. Sejak saat itu maka setiap warga yang membutuhkan pinjaman dengan jaminan hasil panen kelapa sawit selalu dapat terlayani oleh toke. Akibatnya adalah penjualan TBS oleh petani tidak lagi dapat doikontrol oleh koperasi. Demikian pula pengembalian pinjaman ke bank menjadi tidak lancar. Koperasi kemudian 'lepas tangan' atas permasalahan ini. Sementara pihak BPD Bengkulu tidak dapat melakukan perjanjian kontrak dengan toke perihal dana pinjaman warga dengan skema KKPA.

Untuk dapat mengikat petani secara kontinyu, toke juga banyak menolong petani kelapa sawit untuk berbagai keperluan. Para toke bersedia memberikan pinjaman uang kepada petani untuk berbagai keperluan hingga sepuluh juta tanpa bunga. Bahkan ada toke yang tidak membatasi jumlah pinjaman. Jaminannya adalah kebun kelapa sawit. Konsekuensinya adalah kelapa sawit yang tak dapat dijual kepada pihak lain, karena sudah menjadi komitmen bahwa pembayaran dilakukan pada saat panen kelapa sawit. Persoalannya adalah petani tidak tahu persis berapa harga sawit di tingkat pabrik. Mereka hanya tahunya dari toke berapa pun harga yang disebutkan oleh toke. Berbeda halnya dengan kalau situasinya tidak ada ikatan, petani bisa melakukan konfirmasi ke pabrik dan atas dasar itu petani bisa melakukan tawar menawar dengan toke.

\section{OPERASIONALISASI KERANGKA KEBIJAKAN NASIONAL TENTANG PENANGGULANGAN KEMISKINAN}

\section{Tolok Ukur Kemiskinan: Cara Pandang Pemerintah versus Masyarakat}

Keanekaragaman pola hidup serta latar belakang sukubangsa menyebabkan persepsi tentang keadaan sosial budaya yang dianggap sebagai kemiskinan berbeda-beda pula, dan ini sangat terkait dengan pola hidup masyarakatnya serta masalah yang dialaminya sebagai masalah sosial, khususnya berkaitan dengan sosial ekonomi. Dari gambaran data penelitian yang telah dilakukan terdapat beberapa tolok ukur yang dijadikan patokan sebagai orang miskin, dan pada umumnya terkait pada kelompok kekerabatan dan bukan pada keluarga batih. Gambaran ini dapat dikategorikan berdasarkan kelompok keluarga luas, kelompok desa, egaliternya perasaan senasib dan mata pencaharian yang dilakukan.

Dari data yang diperoleh tampak seakan tolok ukur kemiskinan mencakup kecilnya penghasilan yang diperoleh keluarga batih (inti), keadaan kondisi kasat mata kehidupan sehari-hari dapat dikatakan tidak layak dari segi kesehatan, dan bahan-bahan rumah tinggal dari bahan yang sederhana. Akan tetapi dari keseluruhan data yang diperoleh terdapat kesamaan bahwa keadaan kasat mata dan kondisi sandang dan papan bukanlah tolok ukur utama kemiskinan. Pada umumnya yang dijadikan tolok ukur kemiskinan adalah perasaan diri yang kurang dari orang lain khususnya akses yang diperoleh dalam hal pendidikan, ekonomi, dan agama. Jadi bukan ketidakpunyaan barang dan 
pekerjaan serta kondisi rumah yang dipunyai oleh seseorang atau sebuah keluarga batih.

Hal ini sangat berbeda dengan tolok ukur yang didasari pada konsep pemerintah yang memandang dari segi ekonomi serta keadaan kondisi kehidupan sehari-hari masyarakat. Sehingga penanggulangan kemiskinan atau program pengentasan kemiskinan yang dilakukan oleh pemerintah terlihat tidak berhasil menghilangkan apa yang dirasakan oleh masyarakat sebagai kondisi miskin.

\section{Proses Penanggulangan}

Untuk mengatasi perbedaan keadaan sosial ekonomi penduduk yang dinyatakan sebagai miskin menurut persepsi penduduk, maka banyak masalah-masalah kemiskinan yang diderita tersebut diatasi melalui kemampuan adat kebiasaan sehari-hari penduduk yang secara arif berfungsi satu dengan lainnya. Programprogram pengentasan kemiskinan yang dilaksanakan oleh pemerintah pada prinsipnya dilaksanakan dengan menggunakan persepsi masyarakat, sehingga sering terjadi ketidaktepatan antara cara dan capaian yang ditetapkan oleh pemerintah dengan cara dan capaian yang dilaksanakan oleh masyarakat.

Bantuan program pemerintah diterima oleh keluarga yang dianggap miskin berdasarkan persepsi dari pemerintah, yaitu kondisi ekonomi dan keberadaan rumah, tetapi dana bantuan tersebut dibagikan kepada tetangganya satu desa yang mempunyai kondisi serupa. Kebersamaan sebagai anggota masyarakat se desa sangat diutamakan, seperti tergambar pada masyarakat di Yogyakarta. Pada bagian lain program pemerintah bahkan dibantah dan ditolak karena dirasa sangat merendahkan keluarga luas dari individu yang dikategorikan sebagai orang miskin, seperti yang tergambar di masyarakat Minangkabau di Sumatera Barat. Program-program pengentasan kemiskinan juga dilaksanakan oleh beberapa pihak swasta seperti korporat dan juga lembaga-lembaga swadaya masyarakat dengan kriteria yang berbeda-beda satu dengan lainnya.

Beberapa kelembagaan sosial yang formal turut memberikan andil dalam melaksanakan program pengentasan kemiskinan, dan pada umumnya kelembagaan sosial ini didasari pada latar belakang kelembagaan itu sendiri. Seperti agama yang melihat dan mencari celah dari aspek keagamaan dalam program atau pelaksanaan program pengentasan kemiskinan, kelembagaan adat yang berusaha untuk merubah pelaksanaan program yang dari pemerintah dan disesuaikan dengan cara dan capaian dari kelembagaan itu sendiri.

Perbedaan cara dan capaian dalam melaksanakan program pengentasan kemiskinan yang dialami oleh masyarakat dan dilaksanakan oleh kelembagaan lokal ternyata tidak sama atau tidak sesuai dengan rancangan yang dilaksanakan oleh pemerintah, sehingga seakan program pengentasan kemiskinan banyak yang tidak mencapai sasaran atau dianggap menyimpang dari sasaran.

Terdapat juga sistem pemberian bantuan penanggulangan kemiskinan yang dipahami sebagai kegiatan rutin yang apabila tidak habis terserap maka akan menjadi 'hangus', sehingga dana untuk kegiatan berikutnya akan menyusut. Oleh karena itu harus dihabiskan. Disini tampak bahwa sistem pelaksanaan program menjadi sebuah proyek yang harus ada pada setiap tahunnya. 
Ketika ditanggapi secara berbeda oleh masing-masing sektor, maka terjadi tumpang tindih orang-orang yang dinyatakan miskin, yang masing-masing lembaga baik pemerintah maupun swasta, mengidentifikasikannya. Sehingga menyebabkan pencatatan ganda tentang orang yang sama yang dianggap miskin, dan juga terdapatnya orang-orang yang sebenarnya dikategorikan oleh masyarakat setempat bukan orang miskin, dan bahkan jumlah orang miskin akan bertambah banyak ketika lembaga-lembaga menggunakan persepsi yang berbeda-beda.

Dari adanya berbagai konsep tentang orang miskin berdampak pada jumlah orang yang dikatakan miskin yang semakin banyak, dan bahkan mempunyai kriteria yang masing-masing berbeda. Ini menyebabkan terpengaruhnya proses bantuan bagi orang-orang miskin yang bersangkutan. Proses ini sangat berkaitan dengan perangkat aturan atau pedoman yang digunakan. Kebiasaan sehari-hari masyarakat dengan mengandalkan orang-orang dominan secara adat akan senantiasa atau sering bertolak belakang dengan orang-orang yang ditunjuk secara formal melalui lembaga formal pemerintah.

Keadaan ini sering menyebabkan munculnya ego sektoral yang berdasarkan pada kelompok-kelompok kecil masyarakat atau clique dan berpotensi menciptakan stereotype baru bagi pengelompokkan tersebut. Sifat egaliternya masyarakat dapat mempengaruhi proses penyebaran bantuan, seperti seorang penerima bantuan akan membagikan kepada rekan yang sama-sama dianggap senasib akan tetapi tidak mendapatkan bantuan, atau dapat juga terjadi penyimpangan bantuan karena adanya kelompok yang memegang dominasi di masyarakat.

\section{MEMAKNAI KEMBALI KEARIFAN LOKAL DAN PERANANNYA DALAM PENANGGULANGAN KEMISKINAN}

Pola-pola yang muncul dari pemahaman terhadap tindakan yang muncul yang digambarkan oleh individu-individu sebagai anggota masyarakat pada dasarnya tidak dapat dipahami dari sudut pandang lembaga atau kelompok dari luar masyarakat yang bersangkutan. Sehingga pemahaman dan pemaknaan dari gejala sosial yang ada dalam suatu lingkungan masyarakat harus dipahami berdasarkan persepsi dari masyarakat yang bersangkutan. Hal ini menyangkut makna atau simbol yang dipahami masyarakat adalah kriteria yang diberikan oleh masyarakat itu sendiri atau menjadi tolok ukur yang 'disetujui' oleh masyarakat setempat. Biasanya untuk memudahkan suatu program pengembangan kesejahteraan masyarakat dan penanggulangan masalah sosial yang ada dalam masyarakat hal yang paling cepat memberikan hasil adalah dengan mengidentifikasi masalah sosial yang muncul dalam kehidupan masyarakat. Dengan melihat masalah sosial berarti akan tampak ketimpangan-ketimpangan tindakan-tindakan yang dapat dikatakan melanggar 'pakem' atau pola yang sudah ada dalam masyarakat. Sehingga dengan demikian penggambaran suatu bentuk kehidupan sosial masyarakat dapat diidentifikasikan dengan jelas dan fungsional dalam sistem yang sudah ada dan bekerja sebelumnya. 
Titik-titik penting yang bisa disebut sebagai masalah sosial itu adalah:

(1) Sesuatu yang secara luas dipertimbangkan sebagai suatu yang "jelek" atau "buruk" dari suatu hal, kejadian atau tindakan.

(2) Melibatkan jumlah orang yang banyak (dalam hal ini komuniti / masyarakat atau organisasi atau kumpulan orang yang memiliki keterikatan baik secara moral, hukum atau administrasi)

(3) Sering, walaupun tidak selalu, dirasakan telah memberikan kerugian bagi masyarakat atau kelompok orang tertentu.

Sebagaimana yang kita ketahui bahwa dalam memahami segala suatu yang ada dalam lingkungannya, maka manusia sebagai anggota komuniti tertentu akan menggunakan kebudayaannya. Itu lah sebabnya kenapa budaya suatu komuniti akan berbeda degan komuniti yang lainnya. Sehingga ini juga menyebabkan perbedaan sudut pandang bagaimana cara masing-masing dari komuniti tersebut mengkondisikan bentuk-bentuk dan tipe-tipe dari masalah sosial yang ada dalam komuniti bersangkutan.

Jadi masalah sosial dapat dimaksudkan sebagai hasil dari suatu interaksi antara perwujudan kebudayaan dalam bentuk tindakan-tindakan yang dimunculkan oleh pelaku sebagai anggota masyarakat yang dengan pemahaman individu-individu yang berinteraksi tersebut dengan menggunakan pengetahuan kebudayaan yang dimilikinya masing-masing. Perwujudan tindakan sebagai hasil pemahaman tersebut bisa berbeda antara satu dengan yang lain dan bisa menimbulkan perbedaan hasil (Rudito dan Budimanta, 2004).

Masalah sosial akan selalu muncul dalam kehidupan manusia sebagai anggota masyarakat dalam mengisi kehidupannya. Kehidupan masyarakat yang digambarkan sebagai pola-pola tindakan dari individu-individunya sebagai anggota akan selalu berubah setiap saat dan perubahan tersebut bisa terencana dan bisa juga tanpa disadari oleh individu-individu yang terlibat di dalamnya. Perubahan-perubahan sosial yang ada dalam masyarakat tidak sejalan dengan perubahan budaya yang dipakai sebagai pengetahuan dalam memahami lingkungan yang ada, sehingga akan terjadi kesenjangan dalam pemahaman gejala sosial yang ada, atau akan terjadi kesenjangan dalam memahami perubahan sosial yang ada.

Perubahan kebudayaan yang dipakai sebagai alat untuk memahami lingkungan sosial tersebut akan terjadi secara lambat, yaitu perubahan yang terjadi pada sistem pengetahuan, nilai dan norma serta aturan guna mengikuti perubahan sosial yang ada agar dapat beradaptasi. Perubahan gejala obyektif dan penilaian secara subyektif ini akan menciptakan masalah sosial bagi individu secara anggota masyarakat. Atau dapat dikatakan sebagai ketidakcocokan antara pengetahuan budaya yang dimiliki oleh anggota suatu masyarakat dengan keadaan nyata yang harus dipahami dan diinterpretasi oleh anggota masyarakat tersebut sehingga memunculkan perbedaan penafsiran karena digunakan kebudayaan yang berbeda. Sehingga antara kenyataan dengan pemahaman kebudayaan terjadi keguncangan (culture shock), akan tetapi biasanya keadaan ini dapat ternetralisasi dengan sendirinya karena manusia bersifat adaptif. Semakin kompleksnya kehidupan bermasyarakat, seperti sering terjadinya 
akulturasi antar masyarakat yang berbeda maka sering terjadi masalah-masalah sosial.

Dalam konteks ini yang dimaksud dengan akulturasi adalah suatu proses percampuran antar budaya yang dibawa oleh seorang atau beberapa orang anggota masyarakat pendukung suatu budaya tertentu dengan budaya yang dibawa oleh seorang atau beberapa orang pendukung budaya yang berbeda. Proses percampuran tersebut mengakibatkan sebagian dari budaya luar terpakai dan menjadi bagian dalam budayanya sendiri.

Sifat kebudayaan yang selalu adaptif dan statis lebih didorong oleh kemampuan konteks kebudayaan yang dimiliki oleh suatu masyarakat atau komuniti. Adaptif artinya mampu untuk berstrategi karena lingkungan yang selalu berubah. Sedangkan statis dimaksudkan selalu dapat dijadikan sebagai pedoman tingkah laku sehingga menjadi tradisi.oleh karena itu kearifan lokal yang menjadi inti dari tradisi suatu masyarakat menjadi titik penting dalam usaha mengembangkan masyarakat menuju kearah kesejahteraan hidupnya dengan memberikan akses kepada kemampuan pengetahuan lokal tersebut untuk menyelesaikan masalah-masalah sosial yang ada di sekitar masyarakat itu sendiri.

\section{NEGOSIASI DAN REVITALISASI KEARIFAN LOKAL}

Kearifan lokal merupakan pengetahuan yang dimiliki oleh masyarakat dalam memandang dunianya, lingkungannya dan mewujudkan tingkah laku serta kebiasaan yang sesuai dengan lingkungan yang dihadapinya. Segala masalah sosial yang berkenaan dengan masyarakat akan mempengaruhi daya adaptasi dari kebudayaan atau pengetahuan yang ada sebagai kearifan lokal. Jadi kearifan lokal adalah perangkat-perangkat model kebudayaan dan/atau pengetahuan yang secara selektif dapat digunakan untuk memahami dan menginterpretasi lingkungan yang dihadapi dan untuk mendorong dan menciptakan tindakan-tindakan yang diperlukannya. Kebudayaan dan/atau pengetahuan itu dipakai oleh manusia untuk mengadaptasikan diri dengan dan menghadapi lingkungan tertentu (fisik/alam, sosial dan kebudayaan) untuk dapat tetap melangsungkan kehidupannya dalam pemenuhan kebutuhan dan untuk dapat hidup lebih baik lagi.

Karena setiap kebudayaan itu sebenarnya merupakan sebuah pedoman, atau patokan menyeluruh bagi kehidupan masyarakat yang mendukung kebudayaan yang bersangkutan, maka kebudayaan itu bersifat tradisional (cenderung menjadi tradisi-tradisi yang tidak dapat mudah berubah). Kecenderungan dari sifat tradisional kebudayaan tersebut disebabkan oleh kegunaannya sebagai pedoman kehidupan yang menyeluruh (Suparlan, 2004:166). Tetapi lingkungan yang dihadapi oleh manusia dalam lingkup masyarakat mempunyai kecenderungan selalu berubah baik secara kualitas, dan maupun macamnya maka ini akan mempengaruhi kebudayaan sebagai pedoman dalam memahami lingkungan tersebut dan kebudayaan tersebut selalu bersifat adaptif. Jadi secara tidak langsung, kebudayaan dalam suatu masyarakat mempunyai kecenderungan untuk berubah setiap saat dan bersifat dinamik. Dari kedua sifat ini, yaitu satu pihak kebudayaan akan selalu bersifat tradisi karena dipakai sebagai pedoman yang menyeluruh (bersifat tidak mau berubah), dan di pihak lain dituntut untuk bersifat 
adaptif (selalu berubah) karena lingkungannya berubah, maka sifat kebudayaan akan tergantung dengan lingkungannya dan juga tergantung dari kuatnya inti budaya yang ada. Hal ini aklan menentukan cepat lambatnya suatu kebudayaan mengalami perubahan.

Disamping terdapatnya proses perubahan kebudayaan dari sudut lingkungan dan juga dari sudut kebudayaan itu sendiri karena adanya dorongan penemuan baru, pertambahan jumlah penduduk, maka terdapat juga perubahan-perubahan pada tingkat sosial, yaitu perubahan-perubahan yang terjadi di pranata-pranata sosial masyarakat yang dapat pula merubah kebudayaan sebagai pedomannya dan dapat juga tidak merubah kebudayaan yang ada. ini terkait dengan perubahan kebudayaan itu sendiri, dan bila mengikuti pendapat Parsudi Suparlan (2004:167) dikatakan bahwa, pada dasarnya perubahan kebudayaan itu berupa suatu modifikasi yang terjadi dalam perangkat-perangkat ide dan yang disetujui secara sosial oleh para warga masyarakat.

Perubahan kebudayaan itu dapat terjadi pada isi struktur ataupun konfigurasi dan cara-cara hidup tertentu. Perubahan kebudayaan itu dapat terjadi pada bentuk, fungsi atau nilai-nilai dari unsur terkecil (trait), unsur yang lebih besar (complex), atau juga pada pranata-pranatanya (institutions). Dengan demikian, cepat atau lambatnya sebuah kebudayaan dalam proses perubahannya tergantung pada arah pedoman yang dipakai oleh manusia sebagai anggota masyarakat dalam acuan yang dijadikan pedoman yang bersifat menyeluruh. Sehingga terdapat kecenderungan kebudayaan untuk bersifat tetap dan sulit berubah karena dijadikan pedoman dalam kehidupan manusia, dan dengan pedoman yang mengarah pada inti budaya dan memberikan arahan pada pranata-pranata sosial yang ada ini, maka integrasi dalam kebudayaan dapat dikatakan masih dapat dipakai sebagai pedoman untuk bertindak dan bertingkah laku guna memahami lingkungannya yang selalu mengalami perubahan.

Pengetahuan dan teknologi dalam suatu kebudayaan pada dasarnya menduduki posisi terdepan berhadapan dengan lingkungan, dan berturut-turut di belakangnya adalah sistem ekonomi, yang kemudian ditunjang oleh sistem keyakinan, kekerabatan, kesenian, dan bahasa. Semua ini didorong oleh kebutuhan manusia itu sendiri berupa: kebutuhan biologis (seperti bernafas, makan, minum, buang air dan meneruskan keturunan); kebutuhan sosial (seperti kebutuhan bergaul dengan sesama orang lain, dan bergaul dengan mahluk lain); dan kebutuhan psikologis (seperti rasa aman, dan sejahtera). Kebutuhan-kebutuhan manusia tersebut akan dipenuhi dengan menggunakan kebudayaannya masing-masing, yang dalam mewujudkannya untuk perwujudannya memenuhi kebutuhan tersebut akan berbeda-beda satu dengan lainnya. Namun demikian, pada masa sekarang perkembangan kebudayaan semakin cepat dan hubungan antar sukubangsa sering terjadi sehingga tidak menutup kemungkinan adanya pola hidup yang bercampur, dan satu sukubangsa dapat saja mempunyai dua atau tiga pola hidup sekaligus. Ini diakibatkan oleh adanya percampuran kebudayaan dalam bentuk percampuran pengetahuan budaya yang dipunyai oleh masing-masing kelompok sosial, sehingga merubah dan menggeser pola-pola pengetahuan yang ada sebelumnya.

Dari kesemua contoh dan pernyataan di atas, maka dapat terjadi bahwa semuanya menggambarkan adanya identitas dari sebuah kelompok sosial terhadap kelompok 
sosial lain dalam berinteraksi, kemudian juga terdapatnya sebuah tataran pedoman yang disepakati sesama anggota kelompok sosial untuk berinteraksi dan menciptakan jatidiri dari masing-masingnya. Dari contoh di atas juga tampak bahwa mengikuti perkembangan waktu serta hubungan antar penduduk, maka kita dapat memahaminya bahwa sukubangsa dengan kebudayaan adalah dua buah konsep yang terpisah dan tidak dapat dicampur-adukkan, kemudian terdapatnya konsep pola hidup yang sangat terikat dengan adanya lingkungan tempat tinggal guna pemenuhan kebutuhan hidupnya.

Pengembangan kesejahteraan sosial atau juga pembangunan komuniti (community development) termasuk didalamnya program pengentasan kemiskinan dapat dilaksanakan dengan penerapan yang sesuai melalui kacamata komuniti setempat sebagai obyek sasaran. Pelaku-pelaku pengembang setidaknya mempunyai muara program yang diimplementasikan melalui satu badan atau organisasi sebagai koordinasi penerapan program pengentasan kemiskinan.

Swasta dalam hal ini korporat mempunyai program tanggung jawab sosial perusahaan dapat memberikan kontribusinya berupa pendanaan yang diberikan kepada masyarakat melalui badan koordinasi ini, begitu juga pemerintah dan lembaga-lembaga lain sebagai swasta. Kesemua ini tidaklah dapat berjalan begitu saja tanpa mengkaitkan dengan modal sosial (sosial capital) dari masyarakat yang menjadi sasarannya. Modal sosial disini tentunya berkaitan dengan kearifan lokal masyarakat.

Kearifan lokal yang berkembang di masyarakat, pada dasarnya merupakan strategi adaptasi yang memang muncul dari dalam masyarakat itu sendiri dalam membenahi masalah-masalah sosial yang berkenaan dengan kehidupan masyarakat itu sendiri. Kearifan lokal merupakan hasil interaksi antara masyarakat dengan lingkungannya, sehingga dengan kearifan lokal, sangat diperlukan untuk membantu masyarakat itu secara mandiri.

Masyarakat Indonesia pada dasarnya tidaklah dapat disamaratakan sebagai satu masyarakat dengan persepsi tunggal. Masyarakat indonesia dapat dikatakan sebagai berbentuk majemuk dan bersifat multikultur. Artinya sebuah masyarakat dengan berbagai kebudayaan sukubangsa yang disatukan oleh sistem politik nasional sebagai budaya nasional, akan tetapi budaya-budaya sukubangsa tetap hidup dalam kehidupan sosial masyarakatnya. Disamping itu masyarakat Indonesia juga bersifat multikultur yang memberi makna bahwa terdiri dari berbagai macam pola hidup yang dapat dikategorisasikan berdasarkan pada bentuk mata pencaharian.

\section{REKOMENDASI}

Dengan bentuk masyarakat Indonesia yang majemuk dan multikultur maka interpretasi yang terjadi terhadap lingkungan hidupnya (alam, sosial dan binaan) akan berbeda-beda antara kelompok satu dengan kelompok lainnya. Walaupun mempunyai pola hidup yang sama tetapi karena berlatar belakang sukubangsa yang berbeda maka dapat terjadi pemahaman yang berbeda terhadap suatu kondisi. Begitu juga walaupun mempunyai latar belakang sukubangsa yang sama tetapi mempunyai pola hidup yang berbeda, maka tetap saja pemahaman terhadap lingkungannya juga akan menghasilkan bentuk yang berbeda. 
Berdasarkan kenyataan tersebut, maka demi melaksanakan program pengentasan kemiskinan guna meningkatkan kesejahteraan masyarakat, maka perlu kiranya melakukan beberapa aktivitas yang berangkat dari usaha menginventarisasikan konsep-konsep atau persepsi tentang masalah sosial dan juga kemiskinan dari sudut pandang komuniti atau masyarakat yang mengalaminya. Berbagai cara dilakukan dengan usaha mengidentifikasi sukubangsa dengan kebiasaannya dan juga terkait dengan pola hidup sebagai bentuk usaha mata pencaharian dari masyarakat yang ada.

Kearifan lokal menjadi inti dari usaha mengentaskan kemiskinan yang ada dan tumbuh di masyarakat sebagai sasaran dari proses penerapan program pengentasan kemiskinan. Disamping itu, sebagai pemerintah yang melaksanakan dan menerapkan program pemerintah tersebut maka perlu diperhatikan sistem penerapan yang ada yang terkait dengan sistem birokrasi pemerintah yang mendominasi budaya nasional. Oleh karena itu sifat kesukubangsaan dan kelompok serta ras dan agama di dalam arena nasional perlu dihilangkan untuk menjaga kewibawaan pemerintah sebagai acuan dalam bertindak dan berinteraksi bagi masyarakat Indonesia secara keseluruhan 